\title{
Childhood Supratentorial Embryonal Tumor, Not Otherwise Specified
}

National Cancer Institute

\section{Source}

National Cancer Institute. Childhood Supratentorial Embryonal Tumor, Not Otherwise

Specified. NCI Thesaurus. Code C114774.

A supratentorial embryonal tumor, not otherwise specified that occurs in childhood. 